\title{
The Construction of the Quality Evaluation System of Multi-angle Tourism Higher Education
}

\author{
Lina Zhong ${ }^{1,2}$, Xiaonan $\mathrm{Li}^{1,2}$, Baolin Deng ${ }^{1,2}$ \\ ${ }^{1}$ School of Tourism Sciences, Beijing International Studies University, Beijing, China \\ ${ }^{2}$ Big Data Institute of Culture and Tourism Research, Beijing, China
}

Email address:

zhonglina@bisu.edu.cn (Lina Zhong), 18731227827@163.com (Xiaonan Li),dengbaolin0225@163.com (Baolin Deng)

\section{To cite this article:}

Lina Zhong, Xiaonan Li, Baolin Deng. The Construction of the Quality Evaluation System of Multi-angle Tourism Higher Education. Higher Education Research. Vol. 4, No. 5, 2019, pp. 70-74. doi: 10.11648/j.her.20190405.12

Received: October 10, 2019; Accepted: October 31, 2019; Published: November 9, 2019

\begin{abstract}
The booming development of tourism also makes some scholars gradually pay attention to the research on the quality of higher education in tourism-related majors, and some research results have been produced in recent years. Many scholars believe that studying the quality standards of tourism higher education is of great significance to the development of tourism higher education. This paper reviews the research contents of higher education quality assessment at home and abroad, and finds that scholars at home and abroad have different views on education quality assessment. Therefore, this paper collects the research articles of domestic and foreign scholars on higher education, classifies and compares their research contents, finds out the shortcomings of domestic education quality evaluation, refers to foreign research experience on education quality evaluation, and explores new directions suitable for domestic education quality evaluation. It is found that the quality assessment of higher education in foreign countries is earlier than that in China. Most of the higher education quality assessment in China is teaching-oriented, while some scholars are teacher-oriented. Only a few scholars conduct teaching assessment comprehensively from the aspects of school, teaching and students. Foreign scholars regard students as the important object of teaching evaluation and give them the most important status. Based on the current research results, this paper constructs a student-centered and multi-perspective tourism higher education quality evaluation system from five perspectives: teaching resources, curriculum evaluation, teaching evaluation and monitoring, teaching output and overall satisfaction of students.
\end{abstract}

Keywords: Tourism Management Major, Evaluation of Education Quality, Student Centered

\section{Introduction}

\subsection{Foreign Higher Education Quality Evaluation Research}

With "Higher education evaluation" as the key word, EBSCO retrieval tool was used to retrieve a total of 6,699 articles on Higher education evaluation from 1980 to 2018.

From the perspective of the number of studies in each period, the research achievements on the quality evaluation of higher education in foreign countries have been increasing year by year. In 1980-1984, there were only 300 research achievements, and in 2010-2014, there were 1,465. In these 39 years, foreign countries have been paying attention to the research on the quality of higher education, and the research achievements have been gradually enriched. In terms of the growth rate of research results, after entering the 21 st century, research results increased faster, indicating that foreign countries paid more attention to the quality of higher education research during this period.

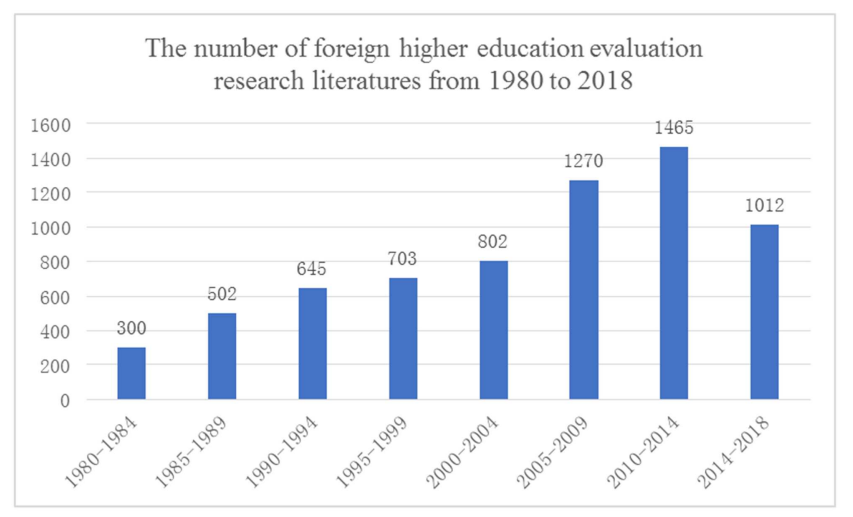

Figure 1. The number of foreign higher education evaluation research literatures from 1980 to 2018. 


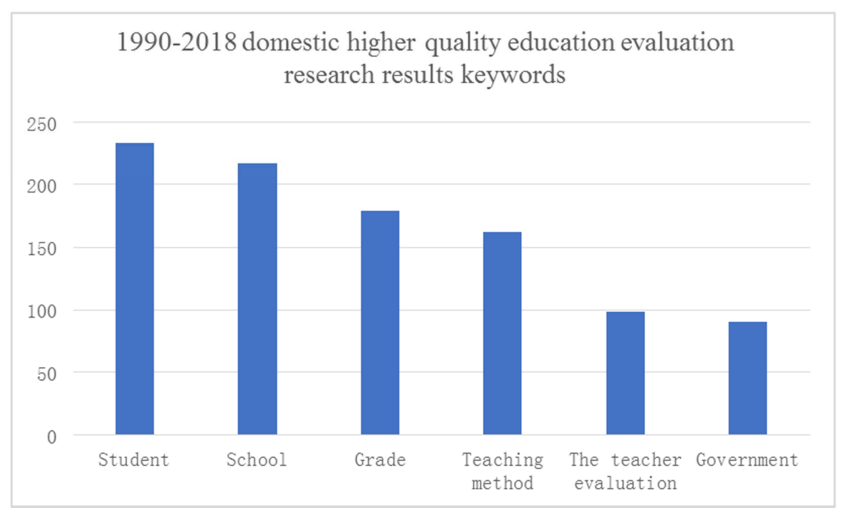

Figure 2. 1990-2018 domestic higher quality education evaluation research results keywords.

From the perspective of research keywords, students are the most studied, followed by schools, grades, teaching methods, teacher evaluation and government. It can be seen that most foreign scholars regard students as the important object of teaching evaluation research and give them the most important status. In the process of teaching evaluation, students' factors are fully considered in foreign countries. In addition, school management has also won the wide attention of many scholars. Good school management is an effective promotion to improve the quality of teaching.

\subsection{National Higher Education Evaluation}

With "higher education evaluation" as the key word, articles on higher education evaluation from 1985 to 2018 were retrieved by using the cnki retrieval tool, and a total of 1434 articles were retrieved.

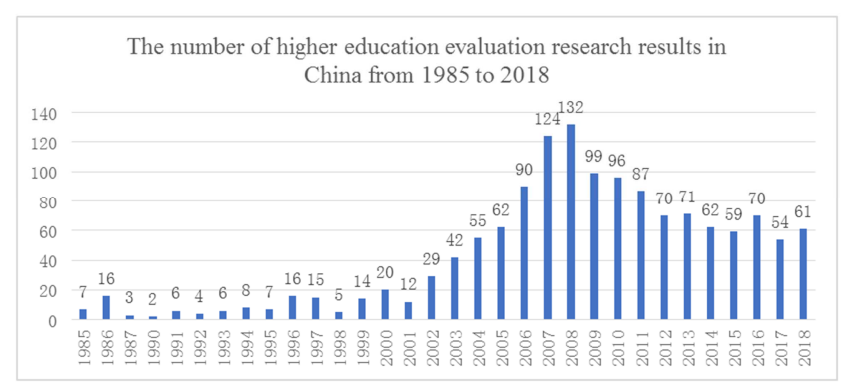

Figure 3. The number of higher education evaluation research results in China from 1985 to 2018.

As shown in Figure 3, judging from the number of research results in each period, China's higher quality education evaluation research has achieved great development since 34 years ago, from 7 research results in 1985 to 132 in 2008. It can be seen that domestic scholars began to study the evaluation of higher quality education gradually. From the overall growth trend, the research results of higher education evaluation increased gradually from 1985 to 2008, gradually decreased from 2008, and then reached a level. From 2007 to 2008, the research results of higher quality education evaluation published by Chinese scholars reached the peak, reaching 124 and 132, which was also the first time to exceed 100. After that, the growth rate of research results slowed down, showing a downward trend.

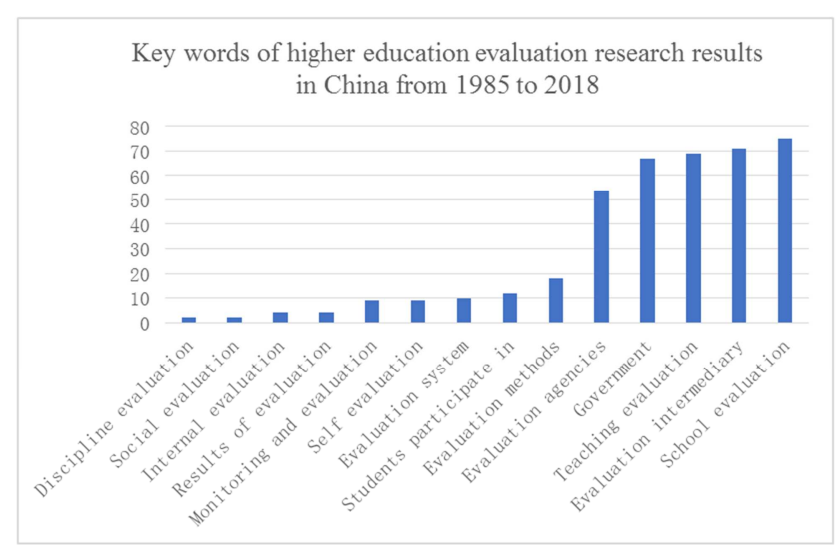

Figure 4. Key words of higher education evaluation research results in China from 1985-2018.

As can be seen from Figure 4, the research results of domestic scholars are mostly based on school evaluation, evaluation agency, teaching evaluation, government and evaluation agency, while the student-centered evaluation is less. It can be seen that the quality evaluation of higher education in China considers more the research on teaching methods and teaching contents, then the personal qualities and abilities of teachers, and finally the students. This form of evaluation is mainly teaching-oriented.

Evaluation of Tourism Management Education Quality

In China, the quality of tourism management education is studied from the aspects of teaching quality, personnel training quality and practical teaching quality. In terms of teaching quality, Xiong Jihong used analytic hierarchy process to establish a teaching evaluation system for tourism management major that was evaluated by students, peers and higher authorities. In terms of the quality of tourism talent training, Hong Meixiang established an evaluation index system for the quality of tourism talent training based on the training conditions, training implementation process and training effect [2]. In terms of the quality of practical teaching, Wang Zhongjun put forward the evaluation system of practical teaching quality from the perspective of school-running philosophy, teaching conditions and teaching management of tourism management specialty [3]. Wang Fuqiang put forward the evaluation system of paper evaluation standard, graduation comprehensive practice post evaluation standard and project evaluation standard [4]. Wang Fengxia evaluated the practical teaching quality of tourism management major from the aspects of students, teachers, process management and practice sites [5]. Gao Weiquan constructed an evaluation system of practical teaching quality for tourism management majors in application-oriented undergraduate universities from five dimensions: practical teaching support system, teaching objectives, teaching content, teaching management and teaching effect [6].

It can be seen from table 1 that most scholars in domestic tourism management education evaluation are teaching-oriented. In addition, some scholars are teacher-oriented in teaching evaluation, while only a few scholars conduct teaching 
evaluation comprehensively from school, teaching and students. In order to improve the teaching quality of tourism management majors in China, it is urgent to establish student-centered tourism education evaluation standards.

Table 1. Overview of the study on the education quality evaluation of management subjects in domestic universities.

\begin{tabular}{|c|c|c|c|}
\hline Author & Evaluation object & $\begin{array}{l}\text { Evaluation } \\
\text { methods }\end{array}$ & Appraisal conclusion \\
\hline Xiong Jihong [1] & $\begin{array}{l}\text { Tourism management } \\
\text { college }\end{array}$ & $\begin{array}{l}\text { The teaching } \\
\text { guidance }\end{array}$ & $\begin{array}{l}\text { The main factors that affect the teaching quality of tourism management major } \\
\text { are teaching attitude, teaching content and teaching method. }\end{array}$ \\
\hline $\begin{array}{l}\text { Hong Meixiang, He } \\
\text { Zhenrui [2] }\end{array}$ & $\begin{array}{l}\text { Tourism management } \\
\text { college }\end{array}$ & $\begin{array}{l}\text { The teaching } \\
\text { guidance }\end{array}$ & $\begin{array}{l}\text { The quality evaluation system of tourism talents training has been established, } \\
\text { which includes training conditions, training implementation process and } \\
\text { training effect. }\end{array}$ \\
\hline Wang Zhongjun [7] & $\begin{array}{l}\text { Tourism management } \\
\text { college }\end{array}$ & $\begin{array}{l}\text { The teaching } \\
\text { guidance }\end{array}$ & $\begin{array}{l}\text { The evaluation system of practical teaching quality is constructed from the } \\
\text { aspects of running school idea, teaching conditions and teaching management } \\
\text { of tourism management specialty. }\end{array}$ \\
\hline Wang Fuqiang [4] & $\begin{array}{l}\text { Tourism management } \\
\text { college }\end{array}$ & $\begin{array}{l}\text { The teaching } \\
\text { guidance }\end{array}$ & $\begin{array}{l}\text { The evaluation system of graduate practice teaching is constructed, including } \\
\text { the evaluation standard of graduation thesis, the evaluation standard of } \\
\text { graduation comprehensive practice post and the evaluation standard of project. }\end{array}$ \\
\hline Wang Fengxia [5] & $\begin{array}{l}\text { Tourism management } \\
\text { college }\end{array}$ & $\begin{array}{l}\text { Comprehensive } \\
\text { orientation of } \\
\text { teaching, teachers } \\
\text { and students }\end{array}$ & $\begin{array}{l}\text { This paper evaluates the quality of practical teaching of tourism management } \\
\text { major from four dimensions: students, teachers, process management and } \\
\text { practice places. }\end{array}$ \\
\hline Gao Weiquan [6] & $\begin{array}{l}\text { Tourism management } \\
\text { college }\end{array}$ & $\begin{array}{l}\text { The teaching } \\
\text { guidance }\end{array}$ & $\begin{array}{l}\text { From the practical teaching support system, teaching objectives, teaching } \\
\text { content, teaching management and teaching effect five dimensions to construct } \\
\text { the practical teaching quality evaluation system of tourism management major } \\
\text { in application-oriented universities. }\end{array}$ \\
\hline Liu Zhentian [8] & $\begin{array}{l}\text { Tourism management } \\
\text { college }\end{array}$ & $\begin{array}{l}\text { The government } \\
\text { guidance }\end{array}$ & $\begin{array}{l}\text { We will improve the evaluation market for higher education, accelerate the } \\
\text { separation of management from management and evaluation, and foster } \\
\text { evaluation intermediaries. }\end{array}$ \\
\hline $\begin{array}{l}\text { Huang Xiujuan, Zhu } \\
\text { Jiajia, Lai Qifu [9] }\end{array}$ & $\begin{array}{l}\text { Fujian Agriculture and } \\
\text { Forestry University }\end{array}$ & $\begin{array}{l}\text { The teaching } \\
\text { guidance }\end{array}$ & $\begin{array}{l}\text { The practice evaluation system of tourism management major in fujian } \\
\text { agriculture and forestry university is constructed, which includes the } \\
\text { orientation of the school's talent cultivation objective, specialty characteristics } \\
\text { and practical teaching objectives. }\end{array}$ \\
\hline Yi Fang [10] & Liaoning University & $\begin{array}{l}\text { The teaching } \\
\text { guidance }\end{array}$ & $\begin{array}{l}\text { The multi-attribute fuzzy analysis and decision-making method is applied to } \\
\text { verify the construction of the education model of "culture + quality + skill". }\end{array}$ \\
\hline Qi Ying [11] & Hainan University & $\begin{array}{l}\text { The teaching } \\
\text { guidance }\end{array}$ & $\begin{array}{l}\text { From the tourism management specialty teaching management, teaching } \\
\text { process, teaching effect, establish the tourism management specialty teaching } \\
\text { quality evaluation system. }\end{array}$ \\
\hline
\end{tabular}

\section{A Student-centered Multi-perspective Tourism Subject Education Evaluation Standard}

"Student-centered" embodies the principle of humanistic psychology. In the 1950s, Carl Rogers, an American humanistic psychologist, put forward the concept of education [12]. Rogers believes that teaching should be "student-centered" and students' "self-realization" is the fundamental requirement of teaching. All teaching activities should be carried out centering on students' "self-realization".

Table 2. Overview of student-centered evaluation methods.

\begin{tabular}{|c|c|c|}
\hline Researchers & $\begin{array}{l}\text { Research content } \\
\text { classification }\end{array}$ & Research conclusion \\
\hline Xu Jiahui [13] & Evaluation index system & $\begin{array}{l}\text { The evaluation system of college education quality constructed in China should be } \\
\text { "student-centered" with Chinese characteristics. }\end{array}$ \\
\hline Su Linqin, Sun Qinjuan [14] & Evaluation significance & $\begin{array}{l}\text { The student-centered evaluation concept should change from outside to inside, the evaluation } \\
\text { subject should change from experts to students, and the evaluation content should change } \\
\text { from school input to student output. }\end{array}$ \\
\hline Zhang Jia [15] & Evaluation index system & $\begin{array}{l}\text { From the point of view of students, teachers' work status is graded and teachers' performance } \\
\text { is evaluated. }\end{array}$ \\
\hline Wang Junhong, Yu Bo [16] & $\begin{array}{l}\text { Evaluation } \\
\text { paradigm formulation }\end{array}$ & $\begin{array}{l}\text { This paper puts forward a set of basic framework to evaluate the quality of college English } \\
\text { teaching from three dimensions: student achievement, student achievement and student } \\
\text { attitude. }\end{array}$ \\
\hline Tian Fang [17] & $\begin{array}{l}\text { Evaluation paradigm } \\
\text { formulation }\end{array}$ & $\begin{array}{l}\text { Take the student as the center to carry on the top-level design analysis to the undergraduate } \\
\text { teaching quality evaluation. }\end{array}$ \\
\hline He Lin [18] & Concept & $\begin{array}{l}\text { A scientific and reasonable closed-loop structure has been formed from the selection and } \\
\text { training of students, the role playing in the evaluation, the writing of students' written reports, } \\
\text { the evaluation and feedback, the management supervision and the improvement. The whole } \\
\text { process embodies the student-centered concept and the separation of management and } \\
\text { management evaluation is the fundamental guarantee for the success of teaching evaluation. }\end{array}$ \\
\hline
\end{tabular}




\begin{tabular}{|c|c|c|}
\hline Researchers & $\begin{array}{l}\text { Research content } \\
\text { classification }\end{array}$ & Research conclusion \\
\hline Wei Rongxia [19] & Concept & $\begin{array}{l}\text { The concept of results-oriented education is different from the educational concept mentioned } \\
\text { by psychologist Carl Rogers in teaching practice, which is reflected in different teaching } \\
\text { objectives, teaching methods and teaching evaluation. }\end{array}$ \\
\hline Liu Haiyan [20] & Concept & $\begin{array}{l}\text { "Student-centered learning" emphasizes the dominant position of students in the teaching } \\
\text { process, which corresponds to the teacher-centered teaching paradigm. It is a new educational } \\
\text { teaching paradigm. }\end{array}$ \\
\hline
\end{tabular}

Existing research comprehensively, with students as the center of the characteristics of the evaluation method is to emphasize the students' subject status, it is different with teaching oriented education quality evaluation, it emphasizes the student is the center in the whole teaching process, it will cultivate students ability and cause the student to study as a teaching purpose, it attaches great importance to the students' study effect, it is a kind of advanced and scientific evaluation method.

\section{Conclusion}

From the above review, it can be seen that the quality evaluation of higher education in China is mainly teaching-oriented, with great attention paid to the teaching methods, teaching contents, teaching equipment and the environmental impact of teaching. Some higher education evaluation is teacher-oriented and believes that teachers' personal ability plays a significant role in teaching quality. Other methods mainly involve government orientation and intermediary agency orientation, etc. Generally, there are few research results on student-oriented research. In foreign countries, students are the most studied in education quality evaluation, followed by schools, grades, teaching methods, teacher evaluation and government. Most countries regard students as the important object of teaching evaluation research and give them the most important status, taking into full consideration the factors of students and their subjective views. In addition, foreign countries also pay a lot of attention to the school management, they believe that good school management is an effective promotion to improve the quality of teaching. In general, compared with foreign countries, domestic attention to students is not enough, while domestic attention to schools and teachers is significantly higher than that of foreign countries. Therefore, how to combine the characteristics of foreign evaluation, form a student-centered education quality evaluation of colleges and universities is the problem we need to solve now.

Based on this, this paper establishes the student as the center of higher tourism education quality evaluation system, and multiple points of view contains "curriculum evaluation measurement system", "teaching resource management measurement system", "teaching evaluation and monitoring measurement system", "teaching output quality measuring system" and " overall evaluation of students" five level index system. From the perspective of students, students' evaluation of the school, teachers, curriculum, supervision and harvest as well as their overall evaluation of the school and individuals are studied. Comprehensively evaluate various influencing factors from the perspective of students. (Figure 5)

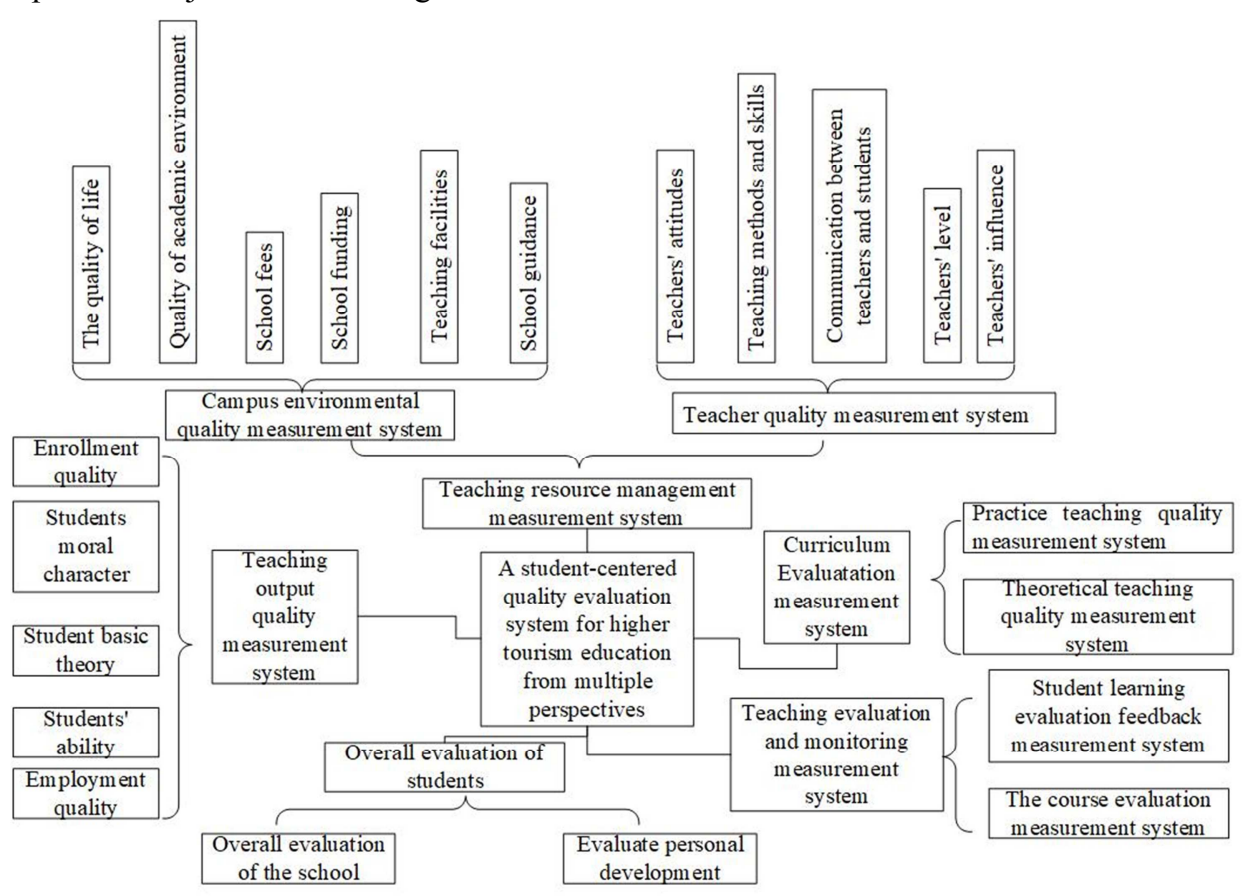

Figure 5. Student-centered quality evaluation system of higher tourism education from multiple perspectives. 


\section{Acknowledgements}

This article was supported by Educational reform project in 2018 funded by Beijing international studies university; and was partially supported by a research funded by Beijing International Studies University (LYFZ18A002).

\section{References}

[1] Xiong Jihong. Study on teaching effectiveness evaluation system of tourism management major in colleges and universities [J]. Journal of higher correspondence (natural science edition), 2009, (01): 25-26.

[2] Hong Meixiang, he zhenrui. Construction of tourism talent cultivation quality evaluation system based on AHP [J]. Journal of economic research, 2011, (03): 173-174.

[3] Wang Zhongjun. Construction of internship teaching quality evaluation system for tourism management specialty $[\mathrm{J}]$. Higher education BBS, 2010, (03): 33-35.

[4] Wang Fuqiang. Construction and implementation of the evaluation system of internship teaching quality of tourism management major [J]. Inner Mongolia education (vocational education edition), 2013, (07): 9-10.

[5] Wang Fengxia. Study on construction of education quality evaluation system for tourism management specialty [J]. Tourism overview (second half), 2014, (07): 325-326.

[6] Gao Weiquan. Construction and implementation of practical teaching quality evaluation system for tourism management major in liaoning province [J]. Journal of jixi university, 2016, $16(03): 22-25$.

[7] Wang Zhongjun. Construction of internship teaching quality evaluation system for tourism management specialty [J]. Higher education BBS, 2010, (03): 33-35. Liu Zhentian. The perfection of China's higher education evaluation system and evaluation market $[\mathrm{J}]$. Higher education development and evaluation, 2014, 30 (04): 19-28.

[8] Liu Zhentian. The perfection of China's higher education evaluation system and evaluation market [J]. Higher education development and evaluation, 2014, 30(04): 19-28.

[9] Huang Xiujuan, Zhu Jiajia, lai qifu. Evaluation of practical teaching objectives in tourism management -- a case study of fujian agriculture and forestry university $[\mathrm{J}]$. Heilongjiang education (higher education research and evaluation), 2018, (02): 1-3.

[10] Yin Fang. Evaluation of teaching quality of tourism management courses based on multi-level fuzzy comprehensive evaluation [J]. Journal of Yellow River conservancy technical college, 2017, 29 (01): 85-87.

[11] Qi Ying. Construction of teaching quality evaluation system for tourism management major [J]. Continuing education research, 2012, (06): 159-160.

[12] Zhou Pingru. Application of humanistic learning theory in teaching [J]. Journal of chongqing three gorges university, 2001, (S1): 221-222.

[13] Xu Jiahui, Zhao Huijuan, Liu Xiulan, et al. "student-centered" evaluation index system of innovation and entrepreneurship education quality in colleges and universities [J]. Heilongjiang animal husbandry and veterinary medicine, 2018, (09): 230-232.

[14] Su Linqin, Sun Qinjuan. Student-centered evaluation: strategic transformation of higher education evaluation [J]. Journal of Beijing xuanwu hongqi amateur university, 2013, (02): 12-13.

[15] Zhang Jia. Practical research on integrated development and implementation of integrated practical activity curriculum and school-based curriculum [J]. Teaching and management, 2015, (09): 33-36.

[16] Wang Junhong, Yu Bo. Evaluation criteria of student-centered English writing textbook $[\mathrm{J}]$. Journal of hubei radio and television university, 2009, 29 (10): 135-136.

[17] Tian Fang. Deepening the teaching reform of higher vocational education by referring to British BTEC teaching model [J]. Journal of hunan university of science and technology, 2006, (03): 236-238.

[18] He Lin. What is the closed-loop structure of student participation assessment in British higher education [J]. Cultural and educational materials, 2018, (28): 88-89.

[19] Wei Rongxia. A brief analysis of the difference between "student-centered" teaching concept and results-oriented education concept $[\mathrm{J}]$. Contemporary education practice and teaching research, 2018, (03): 52-53.

[20] Liu Haiyan. "student-centered learning": the core proposition of teaching reform in higher education in Europe [J]. Education research, 2017, 38 (12): 119-128. 